\title{
A SYSTEMATIC STUDY ON SITE OVERHEAD COSTS IN CONSTRUCTION INDUSTRY
}

\author{
R.Janani ${ }^{1}$, P.T.Rangarajan ${ }^{2}$, S.Yazhini $^{3}$ \\ ${ }^{1}$ Assistant Professor Department of Civil Engineering, Vels University, Chennai, Tamilnadu, India \\ ${ }^{2}$ Assistant Professor Department of Civil Engineering, Vels University, Chennai, Tamilnadu, India \\ ${ }^{3}$ P.G.Scholar Department of Civil Engineering, Vels University, Chennai, Tamilnadu, India
}

\begin{abstract}
Construction sector is the one of the largest employer in the country. It has become a highly competitive field with a minimum profit. Construction costs are two types; one is direct cost (labors, materials, $P \&$ \& Equipments etc...) Other one is indirect costs/Overhead costs (Staff salaries, Staff benefits, Conveyance, Labor miscellaneous, Internet, Watch and ward etc.) and is added as a percentage to sum of labor, material and equipment. Normally 10 to $15 \%$ of contract value will be taken as overhead costs. Overhead costs cannot be neglected, but the indirect costs should be in control always. If the cost goes out of control, the contractors will not be in business. The article discusses about overheads, overhead percentage on contractual value, factor affecting the overhead costs, major issues faced by contractors, how overhead costs affects the income, Engineers/Contractors view on overheads, investigation and control of overhead costs, creating cost awareness among employees, lists out the major items which affects the overheads, interviews with professionals and data collection from the projects and hence creates awareness while bidding and plan the financial resources effectively.
\end{abstract}

Key Words: Overhead costs, bidding, Engineers, Contractors

\section{INTRODUCION}

Before start of a project, construction costs are to be approximately planned. The accurate costs will be known only after the completion of a project. At the initial stage, contractors who are bidding should have the complete knowledge about the Direct and Indirect/Overhead costs. This helps them to control of overheads throughout the project. Overhead costs are very important costs while estimating a building. Overhead costs increases continuously and does not go down. The overhead costs cannot be neglected in any project; these costs constitute a very substantial cost of the project.

The objective of this article is to investigate the overhead costs in construction companies and to find out the major factors affecting the project overheads.

A number of aspects were found in the construction industry and few suggestions are given to control and minimize the overhead costs and to eliminate the unnecessary costs and that is used to manage the overheads in efficient manner.

\section{OVER HEADS}

Overhead costs are said as indirect costs. Overhead costs are not a component of actual construction work but they support the main work. However there are two types of construction overhead costs, Company overhead costs and Project overhead costs. Company overheads are administration costs and the project overheads are site overhead costs.
Site overhead costs will be 10 to $12 \%$ and inclusive of company overhead costs will be $15 \%$ on contract value. If the Overhead cost exceeds $15 \%$, the profit tin project will go down.

Overhead costs are included in every estimate for any type of construction or reconstruction projects which are generally added as a percentage to sum of labor, material and equipment.

List of Site Overhead items are shown in table1,

Table 1: Site Overheads.

\begin{tabular}{|l|l|}
\hline Staff Salaries & Annual Benefits \\
\hline Conveyance & Telephone Charges \\
\hline Printing \& Stationary & Poja Expense \\
\hline Postage and Courier & Xerox \\
\hline Staff Welfare & Insurance \\
\hline Photos \& Videos & Medical Expense \\
\hline Site Accommodation & Bank Charges \\
\hline Watch \& Ward & Freight Charges \\
\hline Testing Charges & Safety \\
\hline Sundries \& Others & Tools \& Tackles \\
\hline Water Charges & Temp Structures \\
\hline Labor Miscellaneous & P \& M for Overheads \\
\hline
\end{tabular}

\subsection{Percentage on Contract Value}

Some of the Overhead items have high percentage on Contract value approximately shown in Figure 1. 


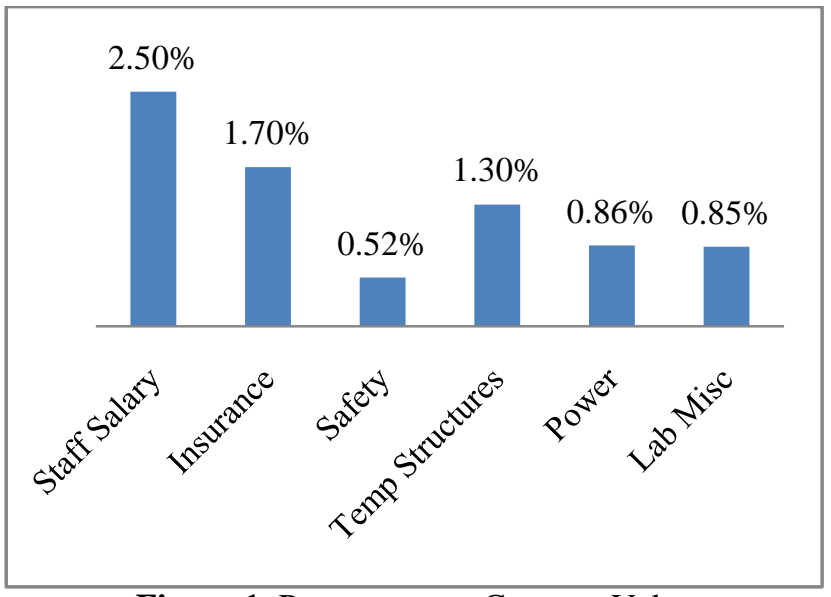

Figure 1: Percentage on Contract Value

\subsection{Scopes of the overheads}

- It shall create the awareness to the contractors / Firms on the importance of Over Head Cost, connected to their industry.

- It shall impart the knowledge to them to plan their financial resources efficiently. It helps in cost awareness among their employees.

- It helps in minimizing Over Head related requirements in their contract documents so that project Over Head costs can be reduced.

It helps in proper cost accounting system in allocating company Over Head costs in a balanced manner.

\section{MATERIALS AND METHODOLOGY}

Some of the Questionnaires were prepared and the answers and the suggestions have been arrived from the Experienced Engineers/Contractors.

Few project reports are reviewed and investigated the reports and interviewed with experienced engineers. The end results has been compared with the reports, answers to the questionnaires and with the interview done with the engineers.

These results shows the many engineers are not satisfied with overhead costs. They are facing a lot of problems to manage the overheads. Hence the investigation is done and suggestions and recommendations given to control and minimize these costs.

From the review, the results have been found that Staff Salaries, Insurance, Safety, Power \& Electricity, Conveyance, Temporary structure, etc... plays a major role affecting the costs. Due to delay in project for various reasons, the time extends and the cost overrun. The delay has to be controlled and the unnecessary spending can be eliminated.

The reasons for delay may be

[1]. Client side delay - late arrival of drawing, change in design.

[2]. Contractor side delay - Lack of workers, improper communication, Delay in materials, Poor workmanship, Poor supervision.

\section{EXPERIMENTAL PROGRAMME}

The research has been done in construction projects by collecting the relevant data from the site and the questionnaires addressed to the Engineers/Contractors. The feedbacks have been collected from the engineers and identified the major factors that affect the overhead costs and suggestions given to minimize the costs.

The major issue which affects the overhead costs is identified and the comparison made with the answers given by the engineers/contractors.

Results shown that, the major items affecting the project site overheads are staff salaries, labor miscellaneous, temporary structures, power etc.

\section{RESULT \& DISCUSSIONS}

The costs for the overheads are not directly mentioned in Bill of quantities. From the review, engineers/contractors are not much aware on overhead costs. Hence the senior engineers/Experience engineers to work out the overhead costs during tender.

Construction companies should carefully examine the contract conditions overhead costs and perform all the necessary precautions to make sure that the project site overhead cost factors are properly anticipated and covered with in the total tender price.

The site overhead costs are mainly affected by the type of project, size of project, area of project, conditions of site.

\subsection{Suggestions Given By The Experienced Engineers}

The project has to be completed on time without any delay, so the overhead costs can be controlled. If delay cannot be controlled then the overhead costs also cannot be controlled. If the project duration increases, then the overhead costs increases.

Delay of materials to site, increases the duration of the project and hence results in increased overheads.

Unnecessary costs can be eliminated and the engineers those who are working on overhead costs should be aware while working out the cost.

Delay in payment indirectly affects the overhead costs.

Experienced Engineers should make Awareness among employees about Overhead costs.

Senior engineers should make alert on other employees about overhead expenses and to supervise/check/investigate the costs regularly.

Periodical review on reports, regular supervision, proper monitor and control on costs helps to eliminate the unnecessary costs.

Reviewing the previous similar projects, and to list out the major factors affecting, and the risks faced by the contractors on overhead items, then to start the estimation on present project overheads.

Senior Engineers have good knowledge on arriving these costs and to be careful during pricing of tenders, proper review on reports, to resolve the conflicts, proper supervision, to solve risks.

Detailed workout on these costs helps to eliminate the unnecessary costs.

Engineers/Contractors should be aware about the 
accurate/exact estimate to avoid damages which may occur. Understanding the overhead works properly will help to control the costs in most efficient manner.

Suggestions given below in Chart 2 can be followed by the engineers/contractors to reduce the overheads cost overrun and to reduce unnecessary spending, and to control throughout the project.

\section{On Time Completion}

Proper Supervision

\section{Reduction in Delay of Materials to} site

Payement of Wages on Time

Awareness among Employees

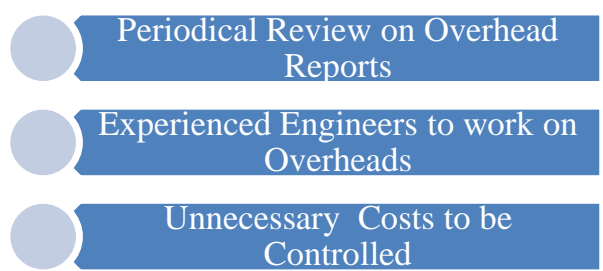

Figure 2: Suggestions to reduce Overhead Costs

\section{CONCLUSIONS}

In order to control the overhead costs in project, the initiated project has to be completed on time without any delay, delayed arrival of materials to project site has to be controlled or it must be eliminated at any reasons, regular review on reports, and regular supervision of project work, delayed payments of wages to employees, proper monitoring and control on costs must be performed.

\section{REFERENCES}

[1]. Assaf. S., A. Bubshait, S. Atiyah, M. Al-Shahri, 2001, The management of construction company overhead costs. International Journal of Project Management. 9: 295-303.

[2]. Swati S Patil \& P.P.Bhangale, Overhead Cost in Construction Industry, India, Vol. 4, Issue 2, Apr 2014, 1-6.

[3]. Van der Vlist, A.J., M.H. Vrolijk and F.J.Janssen, 2010, Firms' Overhead Costs in Real Estate Construction industry, 2006-2008.

[4]. Cilensek, R., (1991), 'Understanding Contractor Overhead', Cost Engineering (AACE), Vol. 33, No.12, 21-23

[5]. Holland, N. and Hobson, D. (1999). (Indirect cost categorization and allocation by construction contractors" Journal of Architectural Engineering, ASCE, 5(2) 49-56.

[6]. Banker. R., Potter. G., Schroeder, 1995, “An empirical analysis of manufacturing overhead cost drivers". Journal of Accounting and Economics 9 115-137.

\section{BIOGRAPHIES}

Janani R, Assistant professor in the department of civil engineering at Vels University, Chennai. Obtained Master of Technology in Construction Engineering and Management from S.R.M University, Bachelor of Engineering from Anna University, Chennai and has industrial experience in reputed multinational companies and reputed colleges and her areas of interest is Construction Management.

Rangarajan P.T, Assistant professor in the department of civil engineering at Vels University, Chennai. Graduated Bachelor of Engineering in Civil Engineering from Thiagarajar college of Enginneering, Madurai, Master of Engineering in Structural Engineering from Anna University, Chennai has published research technical papers and his areas of interest includes Structural Engineering, Concrete technology.

Yazhini S, PG Scholar in the department of Civil Engineering at Vels University, Chennai. Bachelor of Engineering from Anna University, Chennai. 